\title{
Weak of Effects of Music Education in The Establishment of Characters
}

\author{
Herwin Yogo Wicaksono ${ }^{\bowtie}$ \\ Department of Music Education, Faculty Languages and Arts, \\ Universitas Negeri Yogyakarta, Indonesia
}

Submitted: March 19, 2019. Revised: May 6, 2019. Accepted: June 29, 2019

\begin{abstract}
This study discusses the absence of significant influence from music education in shaping an individual's character. Character education itself is an education that discusses the mental and moral qualities that are unique to an individual. Ki Hajar Dewantara views music education as having the power to help Indonesian people realize a better inner and outer life, and the nature of the art of music itself is actually order and beauty. The purpose of this study is to reveal the weak influence of music education on the formation of an individual's character. The behaviour of students and lecturers in the Department of Music Education FBS UNY was observed continuously for approximately six months. To strengthen the data, interviews were conducted face to face. The results showed that most students and lecturers who had long struggled and involved in the music field were weak in terms of discipline, social care and socializing order, and beauty. This can be seen from the behaviour of students and lecturers in carrying out daily activities, especially musical activities.
\end{abstract}

Keywords: Education; Character; Music

How to Cite: Wicaksono, H. Y. (2019). Weak of Effects of Music Education in The Establishment of Characters. Harmonia: Journal of Arts Research And Education, 19(2), 172-178.

\section{INTRODUCTION}

All the elements that make up a community such as a language, religion, history, art, customs, traditions, and norms reflect the culture of that community. This cultural structure varies by community. In other words, every community has the same cultural values carried over from the past (Nart, 2017) religion, history, art, customs, traditions, norms and etc. reflects the culture of that community. This cultural structure varies in each community. In other words, each society has common cultural values brought from the past. One of the goals to be achieved through education is transferring these common values that hold the society together through generations. The most fundamental goal of education which is defined as the process of creating the desired and positive behavior change in individuals is to teach common sense and awareness to individuals. Because, in order to maintain a healthy society and for mana- ging social problems some certain values must be transferred through generations. In this study, with a descriptive method based on the screening model, both values educa- tion and music education which fulfill this function of education, were examined in terms of their influences to each other and to the transmission of the

\footnotetext{
Corresponding author:

E-mail: herwin_yw@uny.ac.id
} 
cultural values. Be- cause, the most important function of both values education and music education, is the positive shaping of an individual's character and therefore social life, through the trans- mission of common cultural values. In conclusion, it is thought that music/music educa- tion is an effective method and tool in the instilling of values. Similarly, in values education, the use of appropriate songs will assist in the instilling of values. Also, through col- lective musical activities children will be able to acquire social and human values (tolerance, sharing, responsibility, friendship, patience, equality, etc.. Likewise, the formation of character, which is so varied in each community, especially in each individual.

The formation of character becomes so important, especially in the modern era and this technological era, where the behaviour of individual experiences a lot of changes. These changes include a lack of communication, mutual respect, and mutual respect so that a sense of solidarity, togetherness, and friendship become faded.

At present, most people are closer to various types of screens, TV screens, mobile phone screens, and computer screens. This condition makes the majority of modern society tend to be individuals who pay less attention to the surrounding environment; they do more activities in front of the screen (Ngafifi, 2014). On the other hand, selfishness, ignorance, aggression, and destructive are dominant in today's society.

These conditions indicate an unfavorable impact on character formation. In addition, this can be said as a phenomenon of moral crisis. Rachmawati (2010) explains that the phenomenon of moral crisis in Indonesia has increased quite rapidly over the past 20 years. Many experts believe that crisis is an indicator of failure in character and spiritual education. However, other studies reveal that there is education that can shape the character of an individual to be positive, namely music education.

Music education is an education that instills various values of goodness, such as discipline, togetherness, social, and mutual respect. Besides, music education also provides a sense of beauty for people who are involved in musical activities. The existence of the inculcation of these virtues from music education for one's life, it can be said that music education can develop the character of people involved in musical activities.

Music as a school subject fulfills objectives related to values and values education more widely in the society by supporting interpersonal relations, creating social cohesion, and laying the foundation for creating and reviving and maintaining the notion of tradition (Muldma \& Kiilu, 2012). Regarding music as a subject the school fulfills goals related to values and education of broader values in society, further Muldma \& Kiilu (2012) explained that music education allows the development of socio-cultural skills in pupils through different musical activities.

This is in line with the results of previous studies conducted by So Yin (2012), who concluded that music is often used by its advocates as a vehicle to promote positive changes in students, academically, emotionally, and socially.

The phrase is reinforced by the results of research conducted by Hallam (2010), who expressed the impact of musical skills on language. This impact is development, literacy, numeracy, measures of intelligence, general attainment, creativity, excellent motor coordination, concentration, self-confidence, emotional sensitivity, social skills, teamwork, self-discipline, and relaxation.

The research findings prove that music can influence the development of a person's character involved in musical activities. Therefore, many studies that examine the formation of the character using music as a medium for the formation of these characters, especially in early childhood, kindergarten, and elementary school level.

The inculcation of values through music education is deemed necessary from an early age. It is said so because, in 
music education, character plays an important role as a determinant of learning success. Character is not only what is written in the curriculum, but is more about students' attitudes in playing music such as responsibility in what they learn, desire to always practice, willingness, interest, readiness, energetic and creative (Sutawi, 2018, p.200).

Ki Hajar Dewantara views music education as an education that has the power to help Indonesian people in realizing a better life and mind. Meanwhile, the nature of music itself is actually order and beauty (Wiratman, 2019). Therefore, it is necessary to form and instill good and positive characters through music education, so that individuals who have good creativity, taste, and intention can be realized.

In line with this, Rachmawati (2010) explains that music, as one of the aesthetic creations, is believed to be able to make a positive contribution to the process of character formation. Meanwhile, character education itself is a planned effort to make students know, care, and internalize values so that students behave as human beings (Haryanto, 2011).

Students who are involved in a musical activity, are not only embedded in cognitive, motor, and affective abilities, but also are embedded in a social sense through cooperative music activities (Djohan, 2009). For example, in a music ensemble game, students who are involved in music activities will form social sense. It is not only the social sense that is formed, but also sensitivity, creativity, and respect (Sutawi, 2018). In addition, in music activities, there is no element of selfishness and still must cooperate with other children as accompanists (Djohan, 2009). In this expression, it appears that students who need to have the nature of respect and respect for one another (with musical accompaniment).

With the results of research that have been described related to music education that can shape the character of an individual, it can be said that music education is a medium to build the character of stu- dents and individual characters involved in it (Sutawi, 2018).

However, based on field studies conducted by observing individual behavior both students and lecturers, this tends to have a character that is contrary to what has been explained from the results of this study.

Though the results of research that explain that an individual who studies music should have a better character, both in terms of discipline, social sensitivity, togetherness, and mutual respect. This becomes an interesting problem for further study, and this is a case. What causes the formation of good characters in individuals who have studied and been involved in musical activities for such a long time.

\section{METHOD}

The case study approach is used in examining the problems in this study. Use case studies, because there are important things from the cases studied, namely the behavior of individuals who have studied the art of music for a long period of time, but does not sufficiently influence the values of character education formed in the person. This case can be said to be a phenomenon both of an individual and a group of individuals (Gerring, 2007; Hancock, et al., 2006), and is a "system bound" by time and place. This was confirmed by (Creswell, 2014), who explained that a phenomenon was tested in several bound systems. Furthermore, Creswell (2014) explains that a case study design can help researchers understand how a case functions in a real-life context. The case referred to in this study is the absence of significant influence from the group of individuals who have studied music for a certain period of time to change and character formation.

This condition is not in line with the findings of previous studies. One of the research findings is produced by (Lee, 2016) that when musical activities are combined with character development, children are better equipped to proactively address problems in their daily lives. These fin- 
dings indicate that the presence of music activities can make children better in overcoming problems in their daily lives. So, it is clear that music activities can shape children's characters to be better in solving problems that arise around them. There are many more research findings that show that music education can shape and develop the character of an individual, and this will be discussed in another part of this research.

The data that has been revealed related to the weak influence of music education on the individual character education of students in the Department of Music Arts Education, FBS UNY, was collected through observation in a certain period of time continuously. Passive participatory observation is carried out both when lecturers and students are active in musical activities, as well as in daily activities undertaken, such as teaching, learning, and socializing.

The observational data, strengthened by data obtained through interviews conducted face to face, both to 4 students and 2 lecturers. Interviews are conducted using unstructured types because they can be done more freely and do not use interview guidelines systematically. In addition, respondents were chosen purposively because of the characteristics that are typical of these respondents, and adjusted to the purpose of the study (Anggito, 2018).

The data that has been collected is obtained for six months (July-December 2017). In this case study research, data were analyzed using an interactive model of Miles, et al. (2014) by the steps of collecting data, reducing data, display data, and making conclusions.

\section{RESULT AND DISCUSSION}

The results of the study described below are related to student and lecturer activities in music processing and daily activities related to their influence on character formation.

In their daily life, students and lecturers in the Department of Music Educa- tion FBS UNY are inseparable from their musical activities, both in theory and in practice. In doing musical activities, sometimes lecturers and students collaborate on a musical performance.

To preparing, regular practice is needed. In the process of this exercise, there are still many character values that seem invisible to the respondents. The character values in question include discipline, mutual respect, and caring for both caring for oneself and caring for the environment and others. This is evidenced by the observations made continuously during music practice. In addition, it was strengthened by an interview conducted with one of the students (Irn) who took part in the exercise, who said that it was difficult to be able to practice on time.

This shows the lack of discipline aspects in determining the time to practice music. Not only is the lack of discipline in terms of time, but there are still many students who lack discipline in reading music scores. Most of the students still focus only on the notes found in the score. Meanwhile, other musical signs such as tempo, dynamic signs, expression signs, key signs, and time signature are not heeded and implemented well into his musical playing. This condition can be seen from the results of interviews with students (Bm and $\mathrm{Ar}$ ) in the guitar class as follows.

\section{"I still have difficulty reading the notation ... so I concentrate on the notes" (Bm). \\ "If I play music, I immediately learn the me- lody of the song, and this I always do, becau- se I want to be able to play music quickly" (Ar).}

Based on the results of the two interviews, it can be said that not all individuals who study and explore music have a good level of discipline. In fact, in the research conducted by Rachmawati (2010), it is said that music as one of the aesthetic creations is believed to be able to make a positive contribution to the process of character formation. Accordingly, based 
on the findings, the results of his research, Rachmawati (2010) recommend that music as a medium can build the foundation of positive and noble characters.

In line with research conducted by Rachmawati (2010), Sutawi (2018) explains the findings of his research on the influence of music education. Music education can form characters, that is, characters that can be formed through music education in schools. There are three flavors, namely, taste (sensitivity), creativity, and respect. However, this opinion is not in line with the findings in this study, as seen in the following interview with Lr and In.

\section{"In playing music, I don't practice routine-} $l y^{\prime \prime}(\mathrm{Lr})$

"I am not interested in joining other friends to play music" (In).

Both of the interview results showed, first, an undisciplined attitude in learning music. It is said so because in learning music, it takes time alone to practice in order to improve skills in playing musical instruments or singing.

Meanwhile, the results of the second interview showed that In had less interest in socializing with friends. Especially friends outside the Department of music education. This is further known as the reason for In's lack of interest in socializing as seen in the results of the following interview.

"my friends out there don't understand, if playing music takes time to practice and prepare, so I tend to be reluctant to play with them." (In).

From the interview results it can be seen that In's lack of interest in socializing with friends outside the Department of Music Education is due to the ignorance of these friends towards attitudes in learning music. However, this shows a slight attitude of not wanting to hang out with other friends besides friends from the $\mathrm{Mu}$ sic Education Department itself.

This condition is also seen when there are other activities outside of music, such as social services, scientific meetings held by the faculty; in fact, student representatives from the Department of Music Education have never participated in these activities. This shows a weakness in socializing, and the situation is contrary to what is expressed by Djohan (2009) that music influences as a tool to enhance and foster personal and social development.

Furthermore, Djohan (2009) said that there are a number of studies that have proven a correlation between music education with critical abilities such as selfesteem, self-discipline, group work skills, analytical skills, and the ability to respect others.

What has been said by Djohan (2009), it can be said that music education is really influential in the formation and development of one's character. In addition, through activities and involvement with cooperative music, social sense will be embedded. This is due to the fact that playing music is inseparable from aspects of the discipline, creativity, self-confidence and social skills, whether working in groups or interacting with others. Thus, these aspects which constitute character formation can basically influence the people involved in musical activities, both directly and indirectly involved.

Hallam (2010) showed that the most frequent overall influences on pupils derived from engagement with the arts in school were related to personal and social development. In music, there were perceived effects relating to awareness of others, social skills, well-being, and transfer effects.

These studies clearly show that music education has a positive influence on character formation. Even in his research, Santosa (2013) explains because of the profound influence of music given to a person, and the resulting changes in manners and habits, the ancient kings in England appointed him as one of the teaching subjects that needed to be included in the curriculum. This is based on the expression of the French philosopher Montesquieu, 
1689-1759 (Santosa, 2013), which says that music is the only art that does not damage the mind.

The statement of the French philosopher was strengthened by the expression of Confucius (Santosa, 2013) which said that "through poetry, one's attention will grow, through various ceremonies someone's character is set, and through one's music becomes perfect". Furthermore, Confucius explained that the preservation of beauty and music is expected to be able to become part of the noble nature of a person and the civilization of society.

The existence of these studies clearly shows the emphasis and affirmation that the magnitude of the influence of music education on character formation. But the results of this study, found aspects that conflict with the influence of music education on the character formation of an individual who has studied music in a long period of time. This situation, as described in the previous section.

Research results obtained based on other observations revealed that there were lecturers who did not appreciate the surrounding environment, each time carrying out an activity. In addition, there is a lack of respect for the environment. This condition can be said that the lecturers lack sensitivity to the surrounding environment. In fact, these lecturers have long been involved in music learning and activities.

In this study, the behavior of lecturers and students is observed every day during activities, both involved in musical activities, or not involved. The results of his research, in addition to those previously described, also seen that the characters that appear are likely to have high egos. In fact, in music education, there are many character values that can affect the lives of most people. However, the results of this study show results that are contrary to the results of research that have been found previously about the influence of music education in shaping one's character. As for the weak influence of music education in shaping the character of someone who is involved with music activities, further research is needed.

\section{CONCLUSIONS}

The results of this study have revealed that the weak influence of music education on character formation, especially social care, order, and beauty, both for lecturers and students who have studied and been involved in musical activities for quite a long time. The lecturers and students tend to lack social skills.

From the results of this research, it can be said that education in the family is the important foundation in character building to further succeed in people's lives. This is as revealed by Ki Hajar Dewanta$\mathrm{ra}$, that family education is the foundation of education for the growth and development of one's character. Ki Hajar's view of education is well known for the Education Trilogy, namely family education, school education, and community education (Haryanto, 2011). Music education is only one of the media that can shape the character of an individual, but family education is the main thing. Thus, it can be said that music education cannot fully develop the character of someone who is learning music. However, there is still a need for integration between family, school, and community education, and family education is the main and basic education for shaping one's character. This is consistent with what was expressed by (Boer \& Abubakar, 2014) that Families are central to the social and emotional development of youth, and most families engage in musical activities together, such as listening to music or talking about their favorite songs.

Based on the results of research that has been obtained, it can be concluded as a whole that family education is the main education, especially in character formation. Music education can shape and develop the character of a person who is involved with music itself, if supported by a strong character base that carries from education in his family, because music was also considered useful in teaching and maintaining 
positive student behavior.

\section{REFERENCES}

Anggito, A. \& J. S. (2018). Metode Penelitian Kualitatif (D. E. Lestari, Ed.). Sukabumi: CV Jejak.

Boer, D., \& Abubakar, A. (2014). Music listening in families and peer groups: Benefits for young people's social cohesion and emotional well-being across four cultures. Frontiers in Psychology, 5(1), 1-16.

Creswell, J. W. (2014). Research Design: Qualitative, Quantitative, and Mix Method Approaches (Fourth Edi). London: Sage Publication.

Djohan. (2009). Kemampuan Musikalitas Sebagai Sarana Pengembangan Keterampilan Sosial. Jurnal Penelitian Dan Evaluasi Pendidikan, 12(1), 111129.

Gerring, J. (2007). Case Study Research: Principles and Practices. Cambridge: Cambridge University Press.

Hallam, S. (2010). The power of music: Its impact on the intellectual, social, and personal development of children and young people. International Journal of Music Education, 28(3), 269-289.

Hancock, D. R. \& Algozzine, B. (2006). Doing Case Study Research. Columbia: Teachers College Press.

Haryanto. (2011). Pendidikan Karakter Menurut Ki Hajar Dewantara. Cakrawala Pendidikan, 2(1), 15-27.

Lee, A. (2016). Implementing character education program through music and integrated activities in early childhood settings in Taiwan. International Journal of Music Education, 34(3),
340-351.

Miles, M. B., Huberman, A. M., \& Saldana, J. (2014). Qualitative Data Analysis, A Methods Sourcebook (Third). Columbia: Sage Publication.

Muldma, M., \& Kiilu, K. (2012). Teacher's View on the Development of Values in Music Education in Estonia. Procedia - Social and Behavioral Sciences, 45(1), 342-350.

Nart, S. (2017). Influences of Music Education and Values Education to Each Other Thru The Transfer of Cultural Values. International Journal of Social Science, 61(2), 77-89.

Ngafifi, M. (2014). Kemajuan Teknologi dan Pola Hidup Manusia dalam Perspektif Sosial Budaya. Pembangunan Pendidikan Fondasi dan Aplikasi, 2(1), 33-47.

Rachmawati, Y. (2010). The Role of Music in Character Building. International Journal of Learning, 17(9), 61-76.

Santosa, B. (2013). Value of Morality in Music of Confucius (551-479). Harmonia: Journal of Arts Research and Education, 13(2), 93-99.

So-Yin, J. M. (2012). Character Development in Music Making: Understanding How Songwriting Can Develop Character. Kingston: Queen's University.

Sutawi, T. K. (2018). Three Characters Moulded in Music Education. Harmonia: Journal of Arts Research and Education, 18(2), 200-207.

Wiratman, A. (2019). Pendidikan Musik Berdasarkan Perspektif Ki Hajar Dewantara. Retrieved from https://www. academia.edu/35168363/Pendidikan_Musik_menurut_perspektif_ Ki_Hajar_Dewantara 